\title{
Colon Micropapillary Adenocarcinoma
}

National Cancer Institute

\section{Source}

National Cancer Institute. Colon Micropapillary Adenocarcinoma. NCI Thesaurus. Code C96492.

A rare, invasive colon adenocarcinoma characterized by the presence of clusters of malignant glandular cells within stromal spaces. 